\title{
Alex Gourevitch* \\ The Limits of a Basic Income: Means and Ends of Workplace Democracy
}

DOI 10.1515/bis-2016-0008

Published online July 13, 2016

Abstract: A democratic economy matters for different reasons, depending on why we are concerned about authoritarian workplaces. Authoritarian work conditions violate overlap but distinct values, related to democratic government, meaningful work, non-domination, exploitation, and the quality of leisure time. To the degree that democratizing work is supposed to advance these values, a basic income is neither a necessary nor sufficient condition for eliminating authoritarian work conditions. It might, in some conditions, reduce some of the worst aspects of our current workplace relationships. But, by the same token, it might exacerbate them, especially if a basic income becomes a substitute for collective self-organization by workers. In nearly every case, the value that we seek to advance and the kind of democratized economy we might wish to have is better created and maintained by concerted class power than by welfarist social policies, like a basic income.

Keywords: basic income, workplace democracy, economic democracy

An employer sends you notice that you must attend a rally for a Presidential candidate. You will not be paid for your attendance and there are strong intimations that you will lose your job if you do not attend (Hertel-Fernandez, 2015). Another employer requires you to spend up to an hour without pay after work in security lines. ${ }^{1}$ Other potential employers are known to fire workers for Facebook comments, for their sexual orientation, for being too sexually appealing, or for not being appealing enough (Hess, 2013; Ramona, 2011; Strauss, 2013; Velasco, 2011). Yet others force their employees to stay home rather than go out on weekends or to switch churches and alter religious practices (Garrison et al., 2015). These are small pieces of evidence that the typical workplace is a site of

\footnotetext{
1 See the recent Supreme Court decision upholding Amazon's right to force its workers, once their shift has ended, to go without pay through sometimes hour-long security screenings to make sure they have not stolen anything (Integrity Staffing Solutions, Inc. v. Busk 574 U.S.)
}

*Corresponding author: Alex Gourevitch, Brown University, Providence, Rhode Island 02912, United States, E-mail: alexgourevitch@gmail.com 
domination not self-government, of arbitrary power not democratic control. Workers are subject to a panoply of rules, directives, orders, commands, whims, caprices, and impositions over which they have no legal control and that they have limited capacity to resist.

\section{The nature of the authoritarian workplace}

Workers are subject to this authoritarian power for three inter-related reasons. One reason is that legislatures and courts have given employers and their managers special grants of legal authority. In the United States these legal powers are called "core managerial prerogatives." Within certain very broad boundaries, bosses are free to make decisions about investment, hiring and firing, plant location, and work process without consulting workers. ${ }^{2}$ For instance, owners may threaten to move a plant overseas if workers threaten to strike, or managers may fire employees whose political views or sexual orientation or even physical appearance they disapprove of. ${ }^{3}$

There are also other legal powers that managers have not by judicial or legislative grant but in virtue of the contractual agreement made with workers. For instance, workers might sign a contract that allows managers to require employees to submit to random drug testing or searches for prohibited substances. ${ }^{4}$ This legal authority is not a core managerial prerogative, rather, it is derived from voluntary agreement among contracting parties.

Finally, managers might have the power to force employees to submit to undesirable features of the job, or even to do things that are prohibited by law like perform sexual favors, change their religious practices, or work in unsafe conditions - simply because of the weak bargaining power of the employee (Garrison, 2015). In these cases, the manager is not exercising any lawful authority to give the specific orders he is giving, but he nonetheless has the power to give these orders. ${ }^{5}$ For the sake of fixing ideas, let us call these three overlapping phenomena "legal prerogatives," "contractual authority," and "raw

2 For a discussion of the injustice of "managerial prerogatives" - the specifically legal powers that employers have - see the important papers Stanczyk and by Anderson (Stanczyk unpublished; Anderson, 2015).

3 On the history and legal content of managerial prerogatives, see Pope (2004); Burns (2011, pp. 47-55) and Atleson (1983, pp. 67-96).

4 On the enormously invasive and widespread character of workplace drug-testing, see American Civil Liberties Union.

5 For criticisms of managerial discretion see (Gourevitch, 2013a; Hsieh, 2005; Stanczyk, unpublished). 
power." The contours of each of these powers and the degree to which they reinforce each other will vary country by country and within countries. But in any capitalist society they hang together to create undemocratic workplaces.

Some have argued that an unconditional basic income (UBI) can democratize the workplace by altering these relationships of power. Being able to fall back on a work-unconditional income means workers have a reasonable alternative to working for an employer. This credible threat to exit work gives them much more power in their relationships with their employers, removing the latters' capacity to exercise uncontrolled power over them. As Frank Lovett argues,

From a domination-minimizing point of view, the distribution goods will be just when it arises from the operation of those political and social institutions and practices most likely to minimize aggregate domination. The configuration of institutions most likely to do this, I have argued, is a free market together with an unconditional basic income (Lovett, 2009, p. 827).

Others, like Philip Pettit, David Casassas, Carole Pateman, Philippe van Pariijs, Kathi Weeks, and Andre Gorz, have made similar arguments in favor of the ability of an unconditional basic income to alter power relationships. ${ }^{6}$ The possibility that a UBI might decommodify labor has even caught the imagination of left-wing public voices who want to make it the basis of a new, socialdemocratic platform (e.g. Frase, 2012). It is quite likely that a universal, workunconditional basic income would reduce unjustifiable economic domination. However, there are a number of difficulties with this approach, both with respect to the means and ends of democratizing the economy.

\section{Clarifying the ends of democratization}

I begin here indirectly, through a discussion of the different reasons to be concerned with workplace authoritarianism and the ends or values that workplace democracy

6 See for instance the important discussion among Pettit (2007), Casassas (2007), and Pateman (2007) in Basic Income Studies 2:2. While Pettit originally defended some kind of "socioeconomic independence" in his first book on republicanism, in the article cited above he explicitly named the basic income as the core guarantee of that independence, and it is now a feature of his more recent restatement (Pettit, 1997, pp. 158-163; Pettit, 2012, p. 112). van Parijs (1992, pp. 3-43) has advanced different arguments for a basic income, but among them are its decommodifying effects. On Gorz's eventual embrace, see van Parijs' reconstruction of Gorz's views, including personal communications with Gorz, in (2009, pp. 1-9). Kathi Weeks provides an important recent version of the Marxist/autonomist defense of basic income as decommodifying (Weeks, 2011, pp. 113-150). 
might promote. With these in mind, we can then see what makes basic income insufficient as a response.

There are multiple reasons to be concerned with the authoritarian nature of the workplace. Here I am drawing on work I have done on what I call 'labor republicanism.' The labor republicans were a group of activists, organizers, and journalists from the late nineteenth century United States who appropriated the republican idea of liberty to criticize wage-labor (Gourevitch, 2015). They argued that a society based on wage-labor had replaced chattel slavery with wageslavery, and that the only way to achieve "a republicanization of labor, as well as a republicanization of government" was to transform the economy into an inter-locking system of producer and consumer cooperatives (Steward, 1873, p.424). While I am drawing on general structures of argumentation from these figures, one does not have to be a republican to find these arguments valid. What follows is compatible with a wide range of socialist, democratic and republican beliefs. The point here is to identify the different ends or purposes that democratic control can satisfy. I crudely distinguish the different ends as: political liberty, non-exploitation, meaningful work, valuable leisure, and nondomination.

One reason for concern with an authoritarian workplace is the corruption of political liberty. The first example I gave in the introduction - of employers coercively influencing worker political behavior - points to this problem. This is an old concern. As one machinist said, in 1870,

Finding themselves able to control vast bodies of men who have voices and votes, [employers] follow them out to their public and private associations, the church, caucus, and at the polls, where as employers they have no business whatever, and with the menace of " $a$ discharge" in their plantation or counting-room manners, they govern and control the votes and conduct of thousands of Massachusetts working men (Massachusetts Bureau of Labor Statistics, 1870 , p. 342). ${ }^{7}$

When workers are dominated by their employers, then they can be unjustifiably constrained in their use of their political and civil liberties. They are not as free as they should be to exercise their will and judgment as independent citizens.

Further, the relationship of profit-making determines the nature of the workrelationship in a way that is usually harmful or unjustifiable to employees. That is to say, it is not just that employers enjoy wide, discretionary power over their employees, but also that employers tend to exercise that power in consistently exploitative ways. Owners have different interests from workers. Owners seek a profit, which means they typically want maximum effort at minimal pay.

7 I am grateful to Chris Michael for pointing me to this quotation. 
Workers want, among other things, maximal pay for minimal effort. This means the practice of profit-making is structured around a basic class tension. Moreover, this tension is not just a question of the subjective desires of owners/managers versus workers. Within limits, the capitalistic logic of the market forces employers to pursue profit-maximizing strategies even if they might personally prefer to be benevolent employers, who offer better conditions and fairer pay. Whether voluntarily, or under competitive pressure, employers will therefore use their arbitrary power in economically rational, exploitative ways. That is why anything from overwork to scheduling rules to undesirable pacing will remain an issue. Even those exercises of power that look purely capricious, having little immediately to do with maximizing efficiency and everything to do with just exercising domination, have a rationality to them. They are about the reproduction of relations of domination that make the profit-making enterprise possible in the first place. So, alongside the corruption of political liberty, the exploitation of workers is a reason to care about democratizing the workplace and the wider economy.

Further, the lack of control over work is directly related to the quality and meaningfulness of the work, not to mention the value of leisure-time. In an authoritarian workplace, excessive hours of labor, the nature of the tasks, or the introduction of certain technologies can make the work stultifying, stunt the development of a person's creative talents, or subvert those powers in the service of ends the worker rejects or would not endorse. Each of these features can turn potentially meaningful work into meaningless, repetitive activity, or take already empty activity and make it substantially worse. When it is the uncontrolled decisions of employers that have this effect - either because they are following market imperatives or because they have made arbitrary decisions about the business - then we can blame the authoritarian workplace for this destruction of the quality of work. Moreover, democratic control over the work can improve the quality of work either by permitting the arrangement and development of tasks in a way that engages and develops our powers, or because it permits the exercise of new, democratic virtues (or both). ${ }^{8}$

Finally, the quality of the work is important not just for its own sake but for what it means about the quality of leisure time. Overwork, frustration and stultification of one's powers carries over in to the enjoyment, or non-enjoyment, of leisure time. So a further reason to be concerned with workplace authoritarianism

8 The relationship between democratic control and meaningful work is rarely discussed, in part because any claims must be made on a conditional and limited basis, but also because it is misleadingly taken to combine two different concerns - craft ethics and democratic authority. For the best discussion, see Elster (1986). 
is the effects on leisure time and, more broadly, on the opportunities for selfcultivation. For instance, the labor republicans that I mentioned before, often celebrated cooperative control over the workplace not because it increased the quality of the work but simply because it reduced the hours of labor, leaving more time for self-cultivation (Gourevitch, 2015, Ch. 4). Collective control served this end either in the sense that, by giving a worker a share in profits it reduced the number of hours it took to earn enough money to live, or because it allowed workers to make decisions about the hours of labor according to shared needs rather than according the profit interests of the capitalist. In the former argument, democratic control included a sense of ownership of the final products while in the latter case what mattered was control in the sense of government. Either way, one of the core aims of late nineteenth century labor republicans, which explained the value of workplace democracy, was "to secure to the workers ... sufficient leisure in which to develop their intellectual, moral and social faculties ... to enable them to share in the gains and honors of advancing civilization" (Powderly, 1886, pp. 30-31). This was important to them not just because long hours did not leave enough time for leisure, but also because there was a limit to which certain kinds of highly technological or routinized work could ever be made particularly fulfilling.

On this view, the promise of modern technology - that it will free all people from the burdens of excessive labor - can only be realized through democratic control over property and work. As one anonymous worker put it, in a cooperative economy, "the laborer shall receive his fair share of the increasing wealth of the country created by his labor, and his proportionate share of the leisure which the inventions of the age permit” (The Master Workman of L A 1573, 1881, p. 160). So workplace democracy is part of the solution to the familiar problem that some stultifying aspects of work have less to do with the profit-interests of the employer and more to do with the technical aspects of industrial or routinized production.

Finally, it should be said that the elimination of the employer-employee relationship can be valued for its own sake. Replacing relationships of domination with relationships of political equality is valuable for its own sake, as a way of increasing the conditions of one's own life that can be understood as a product of one's own will and effort, rather than the product of arbitrary, uncontrolled forces. This is a value sometimes overlooked in arguments about economic democracy because it is often assumed that economic arrangements should promote primarily utilitarian considerations, like well-being, utility, or concern itself with instrumental values like efficiency and productivity.

So, to summarize, there are various ends that democratizing the workplace might promote. In part, democratization is good for the effects it has on the workplace itself: because the degree to which it expands the scope of free action, 
can improve the quality of work, and can establish a new site for the exercise of certain democratic virtues and liberties. In part, workplace democracy can be valuable for its external effects: by improving the quantity and quality of leisure time; establishing the conditions for equal exercise of political liberty; improving the shares one gets from the economy; and by increasing the choices available to people who wish to enjoy some degree of personal autonomy. The group of labor republicans that I have mentioned tended to see these as benefits that went mostly hand-in-hand. But, of course, not all good things go together. An important reason for distinguishing them is because, depending on which ends we care about most, we might think some forms of workplace democratization are preferable to others. It also helps sharpen the focus on just what a universal basic income - or other measures - is supposed to achieve. In fact, I believe I have already taken some steps to showing what is insufficient about many defenses of a basic income: they elide the distinction between actual democratic control over work and having a credible capacity to live without working. Depending on what values we care about, that distinction makes all the difference. In what follows, I would like to sharpen this point by noting the ways in which a universal basic income is insufficient as a means to democratizing the economy.

\section{The insufficiency of the means to economic democracy}

As a means to emancipating workers, the basic income is insufficient, indeed potentially self-undermining, because it focuses primarily on increasing the individual bargaining power of workers as separate market participants. While it is no doubt true that being able to fall back on a work-unconditional income will strengthen an employee's credible threat of exit, which gives her greater capacity to challenge a manager's power, this is entirely a de facto power. It does nothing directly to reduce an employer's legal prerogatives. Nor does it directly challenge the background structure of labor and property law that protects extreme inequalities in the control over property or that limits labor rights. ${ }^{9}$ After all, nobody argues that a basic income should be sufficient to meet not just consumption needs but, over and above that, to be able to save enough such that the recipient could become an owner him or herself. Basic income policies are therefore compatible with enormous inequalities in control over

9 Again, I speak in generalities because there is no room here to compare welfare, labor or property regimes. 
productive resources. In addition, the inherent incompleteness of contracts means that we can never derive the relations of power and authority in the workplace from some ideal of the freely-made contract. ${ }^{10}$ Thus if we care about that kind of active control - say because we care about autonomy or meaningful work or a number of those other values mentioned in the previous section - we have strong reason for doubting the sufficiency of a basic income.

Moreover, a basic income reduces only the asymmetric dependence on employers that springs from having instrumental reasons for seeking a job such as income, benefits, and work-related social standing. But even here, a basic income cannot eliminate many costs associated with losing a job, such as the needs of family, ties to community, value of workplace relationships. Even on its own terms, a basic income alone cannot supply a fully credible freedom to 'exit' such that the labor contract and the ongoing workplace relationship can be seen as free and equal. ${ }^{11}$

Yet even if a basic income could compensate for all of these costs associated with the instrumental value of work, it can do little with respect to the intrinsic values that drive many to work and that thereby create a dependence on employment - and therefore employers. Many will still validly feel an obligation to work and/or they will seek a creative outlet for their capacities or some combination of these motivations. These are sources of an intrinsic value to work, separate from its instrumental value as a source of income. Insofar as the only way to realize these important values will be finding employment offered by that relatively small class of owners of productive property, many will remain unequally dependent on employers. For many, the threat of losing the job will remain a real, coercive threat. Although I cannot discuss it here, the strategy of reducing the value we place in work itself seems to me both undesirable and unfeasible. ${ }^{12}$ Instead, a more fruitful avenue is to seek political means for changing the shared class position of workers in relation to capitalists. That class position is represented both in the wider defense of unequal control over labor and property as a whole, but also in the unequal power and undemocratic structure of the workplace itself.

10 I have discussed this problem at greater length in Gourevitch (2013a). See also Hsieh (2005); Anderson (2015).

11 On the costs of losing the job and limits of basic income see Hsieh (2005, pp. 123-126).

12 I have made some tentative forays into this debate here "The Work Ethic v. The Ethics of Work: A Friendly Reply to Frase" and "Work is (potentially) One Good Thing" posted at my co-authored blog The Current Moment. Gourevitch (2013b and 2013c). 
Now we might think that a basic income is just the kind of policy that would increase class power. But it is just as possible that it could undermine that power. After all, increasing individual bargaining power does nothing to improve or promote the sense that being dominated and exploited is a shared, class position of workers who can best pursue their interests collectively rather than individually. If anything, it could promote the view that we should think of ourselves as consumers first and foremost, who can best pursue our interests atomistically, by maximizing our individual bargaining power as a marketparticipant rather than by joining in collective action. In this sense, a basic income is also potentially "re-commodifying" not just "de-commodifying." The degree to which a basic income in fact promotes democratic values will therefore depend on prior questions of the degree to which it is part of a class-conscious demand to reduce the degree of domination and exploitation in the economy. Indeed, any basic income high enough to threaten existing relations of economic domination would likely only be feasible if there were already a substantial movement among workers. But in that case, we must first give an account of the rights, powers, and activities that go into producing that kind of class power.

\section{An alternative path to economic democracy}

I have suggested that a work-unconditional basic income is insufficient as a means to emancipating workers from the relationships of domination they experience in the workplace. Both at a practical level, in terms of the ability to challenge certain kinds of undemocratic power, and at a substantive level, in terms of being consistent with the values that workplace democracy might satisfy, a basic income comes up short. Here again, I would like to draw on labor republicans to suggest an alternative path acceptable to those interested in economic democracy. This will necessarily be sketchy but it is unified by a single thought: the emphasis should be less on formulating the ideal social policy or the perfect legislative demand and instead on thinking about how those subject to domination could act on their own behalf. There is a good practical reason for this, which comes straight from the historical sociology of domination: who else will do it? As a little-known worker, Langdon Byllesby, once wrote, "history does not furnish an instance wherein the depository of power voluntarily abrogated its prerogatives, or the oppressor relinquished his advantages in favour of the oppressed" (Byllesby, 1826, p. 5). The response that labor republicans generally gave was that workers should organize themselves into political organizations, industrial unions and self-financed cooperatives in order to transform the social and economic order (Gourevitch, 2015, Ch. 5). 
There is strong reason to think that a cooperative economy, based on workplace democracy, cannot be established voluntarily. Those without sufficient capital are at too great a disadvantage in accumulating the savings to set them up in any great numbers. There are also various reasons why cooperatives cannot compete with non-democratic firms, not to mention there is a long history of undemocratic employers colluding to destroy cooperatives - either through legal or illegal means. But there is good reason to think that industrial unionization and class-conscious political organizations are possible and effective. After all, individuals, no matter how great their bargaining power, cannot change laws that grant managers power, that distribute ownership unequally, and that shape the ongoing struggle over political and social control. And the thing about the authoritarian workplace is that it is sustained by a host of shifting, ongoing laws and policies.

The broader point being that, instead of asking about the ideal social policy in terms of its distributional effects or consequences for individual bargaining power, we ought to defend those practices and policies that permit the greatest opportunities for workers to exercise their own collective agency to free themselves from their subjection. We might, in this context, see unionization efforts, strikes, and demands for greater labor rights as the core of the case for workplace democracy not because it will immediately make workplaces democratic, but because it is a necessary step in the formation of the kinds of agents who might demand collective control over their work. That, however, requires not just finding the right policies but thinking through problems regarding collective action, political solidarity, and the rights of the oppressed. After all, the democratization of work and economic life is never the product of one-off acts or single policies - which is an impression that defenders of basic income sometimes give. Rather, it is the product of ongoing struggle, over years and decades, and it lasts only as long as the demand to rule over collective life together remains a living demand of workers themselves. It is unclear to me how a work-unconditional basic income promotes that kind of solidarity. More likely, the relation is reversed. An emancipating social policy will be the product of workers seeking their own emancipation; economic democracy will be the product of economic actors seeking democracy.

\section{References}

American Civil Liberties Union. (1997). Privacy in America: workplace drug testing. https://www. aclu.org/workplace-drug-testing.

Anderson, E. (2015). Equality and freedom in the workplace: recovering republican insights. Social Philosophy and Policy, 31(2), 48-69.

Atleson, J. (1983). Values and assumptions in American labor law. Boston: University of Massachusetts Press. 
Burns, J. (2011). Reviving the right to strike: how working people can regain power and transform society. New York: Ig Publishing.

Byllesby, L. (1826). Observations on the sources and effects of unequal wealth. New York: Lewis J. Nichols.

Casassas, D. (2007). Basic Income and the republican ideal: rethinking material independence in contemporary societies. Basic Income Studies, 2(2), 1-7.

Elster, J. (1986). Self-realization in work and politics. Social Philosophy \& Policy, 3(2), 97-126.

Frase, P. (2012, May 12). Category errors. Jacobin. https://www.jacobinmag.com/2012/05/ category-errors/.

Garrison, J., Bensinger K., \& Singer-Vine J. (2015, July 7). The New American slavery: invited to the US, foreign workers find a nightmare. BuzzFeednews. http://www.buzzfeed.com/jessi cagarrison/the-new-american-slavery-invited-to-the-us-foreign-workers-f\#.nmJN7Yg27.

Gourevitch, A. (2015). From slavery to the cooperative commonwealth: labor and republican liberty in the nineteenth century. Cambridge: Cambridge University Press.

Gourevitch, A. (2013a). Labor republicanism and the transformation of work. Political Theory, 41(4), 591-617.

Gourevitch, A. (2013b). The work ethic v. The ethics of work: a friendly reply to frase. The Current Moment, https://thecurrentmoment.wordpress.com/2013/03/01/the-work-ethic-vthe-ethics-of-work-a-friendly-reply-to-frase/

Gourevitch, A. (2013c). Work is (potentially) one good thing. The Current Moment, https:// thecurrentmoment.wordpress.com/2013/03/14/work-is-potentially-one-good-thing-aresponse-to-livingston-and-other-post-workists/.

Hertel-Fernandez, A. (2015). Who owns your politics? The emergence of employee mobilization as a source of corporate political influence. Washington, DC: New America Foundation. www.newamerica.org.

Hess, A. (2013, July 29). How sexy should a worker be? The plight of the babe in the American workplace. Slate Magazine.

Hsieh, N-H. (2005). Rawlsian justice and workplace republicanism. Social Theory and Practice, 31(1), 115-142.

Integrity Staffing Solutions, Inc. v. Busk. (2014). 574 U.S.

Lovett, F. (2009). Domination and distributive justice. The Journal of Politics, 71(3), 817-830.

Pateman, C. (2007). Why republicanism. Basic Income Studies, 2(2), 1-6.

Pettit, P. (1997). Republicanism: a theory of freedom and government. Oxford: Oxford University Press.

Pettit, P. (2012). On the people's terms. Cambridge: Cambridge University Press.

Pettit, P. (2007). A republican right to basic income. Basic Income Studies, 2(2), 1-8.

Pope, JG. (2004). How American workers lost the right to strike. Rutgers Law School (Faculty Paper).

Powderly, T. (1886). Knights of labor platform - preamble and declaration of principles. In: T. Powderly (Ed.), Labor: Its Rights and Wrongs (pp. 30-32). Washington, DC: The Labor Publishing Company.

Ramona, E. (2011, October 17). 13 controversial Facebook firings: palace guards, doctors, teachers and more. Huffington Post.

Bureau of Statistics of Labor. (1870). Report of the Bureau of Statistics of Labor. Boston: Wright \& Potter, State Printers. 
Steward, I. (1873). Poverty, In Massachusetts Bureau of Statistics of Labor (Ed.), Fourth Annual Report of the Bureau of Statistics of Labor, (p. 434). Boston: Wright \& Potter, State Printers.

Strauss, E.M. (2013, August 2). lowa woman fired for being attractive: looks back and moves in. $A B C$ News.

Stanczyk, L. (unpublished). Marginal liberalism.

The Master Workman of L A 1573. (1881, October 15). An essay on the 'Evils Resulting From Long Hours and Exhaustive Toil.' Journal of United Labor, 2(5-6), 159-160.

Velasco, J.D. (2011, October 7). Fired gay water polo coach and supporters protest at charter oak board meeting. San Gabriel Valley Tribune.

van Parijs, P. (1992). Competing justifications of basic income In P. van Parijs (Ed.), Arguing for Basic Income (pp. 3-43). London: Verson.

van Parij, P. (2009). Political ecology: from autonomous sphere to basic income. Basic Income Studies, 4(2), 1-9.

Weeks, K. (2011). The problem with work: feminism, Marxism, antiwork politics, and postwork imaginaries. Durham: Duke University Press. 